\title{
The Life, Death and Resurrection of British Governance
}

Mark Bevir
University of California

There are numerous accounts of the purported shift from a hierarchic state to a new governance in and by networks. Social scientists typically describe contemporary governance as consisting of something akin to a differentiated polity characterised by a hollowed-out state, a core executive fumbling to pull rubber levers of control, and, most notably, a massive proliferation of networks. Of course, people define governance in all kinds of ways. Nonetheless, social scientists typically appeal to inexorable, impersonal forces such as the functional differentiation of the modern state or the marketization of the public sector to explain the shift from hierarchy to a new governance of markets and especially networks. We will invoke the Anglogovernance school as an illustration of such an approach to governance. More generally, such approaches constitute the first wave of governance narratives.

In this article, we decentre this first wave of governance narratives. To decentre is to focus on the social construction of a practice through the ability of individuals to create, and act on, meanings; it is to unpack a practice in terms of the disparate and contingent beliefs and actions of individuals (Bevir and Rhodes 2003: chapter 4 ). So, we challenge the idea that inexorable, impersonal forces are driving a shift from government to contemporary governance. We argue, instead, that governance is constructed differently by numerous actors operating against the background of diverse traditions. We will again illustrate this argument with the British example. We provide a brief account of the Tory, Liberal Whig and
R. A. W. Rhodes

Australian National University
Socialist traditions and the diverse ways in which elite political and administrative actors have conceived of, and so constructed, distinct patterns of governance. In effect, we pronounce the death of the first wave of governance narratives. We argue, in its place, for the analysis of the various traditions that have informed the diverse policies and practices by which elite actors have sought to remake the state. More generally, we challenge a craving for generality that characterises so many first wave narratives of contemporary governance. ${ }^{1}$

The resurrection of governance requires, we suggest, a decentred approach that focuses on the diverse practices of governance, practices that are themselves composed of multiple individuals acting on changing webs of beliefs rooted in overlapping traditions. Patterns of governance arise as the contingent products of diverse actions and political struggles informed by the beliefs of agents as they arise in the context of traditions. We therefore go on to advocate a definition of governance in terms of a series of family resemblances, none of which need be always present. $^{2}$ There is no list of general features or essential properties that are supposed to characterise governance in each contemporary governance looks like and why it does so. For example, contemporary governance is often characterised in terms of multiplying networks replacing the bureaucratic hierarchies of the welfare state. Such comprehensive accounts of contemporary governance latch on to one or more defining features, where this defining feature then acts as a central focus that allegedly 
explains other pertinent features of contemporary governance. For example, the spread of networks allegedly explains the greater reliance of states on 'trust' and 'diplomatic' styles of management, or it embraces the search for co-ordination through joint ventures, partnerships, and holistic governance.

What do such comprehensive accounts imply about the nature of contemporary governance? They imply, first, that we can define 'contemporary governance' by reference to one or more of its essential properties, such as multiplying networks. They imply, second, that these essential properties are general ones that characterise all cases of contemporary governance: so, we will find governance in its new guise if and only if we find a spread of networks. They imply, finally, that these essential properties can explain at least the most significant other features of contemporary governance.

A comprehensive account of contemporary governance makes sense, even as a mere aspiration, only if these implications are valid. We should seek a comprehensive account only if the way to define and explain contemporary governance is indeed to find a social logic or essential property that is at least common to all its manifestations and ideally even explains them. But why would we assume that contemporary governance has one or more essential features?

The quest for comprehensive accounts appears to arise from a preoccupation with the natural sciences. However, even if it is appropriate in the natural sciences, it is counter-productive in the human sciences. Human practices are not governed by social logics or law-like regularities associated with their allegedly essential properties. They arise instead out of the contingent activity of individuals. Therefore, when we seek to explain particular cases of governance, we should do so by reference to the contingent activity of the relevant individuals, not to a social logic or a law-like regularity. We should explain practices, including cases of governance, using narratives that unpack the contingent actions that embody beliefs informed by contested traditions and dilemmas. The contingent nature of the links between traditions and their development undermines the possibility of a comprehensive account that could relate any one type of practice to a specific set of social conditions as opposed to a historical process. If we pursue these possibilities, we will adopt a decentred approach that negates first wave narratives.

\section{Death: decentring first wave narratives}

\section{Decentred Theory}

It is possible to use differentiation to refer to differences of meaning, or, if you prefer, meaning in action. If we understood differentiation in this way, we might offer a decentred account of governance. We might explore the institutions of governance by studying the contingent meanings that inform the actions of the individuals involved in all kinds of practices of rule. First wave narratives of contemporary governance focus on issues such as the objective characteristics of policy networks and the oligopoly of the political market place; they stress powerdependence, the relationship of the size of networks to policy outcomes, and the strategies by which the centre might steer networks. To decentre governance is, in contrast, to focus on the social construction of patterns of rule through the ability of individuals to create meanings in action. A decentred approach changes our conception of governance. It encourages us to examine the ways in which patterns of rule, including institutions and policies, are created, sustained, and modified by individuals. It encourages us to recognise that the actions of these individuals are not fixed by institutional norms or a logic of modernization, but, to the contrary, arise from the beliefs individuals adopt against the background of traditions and in response to dilemmas.

A decentred approach highlights the importance of beliefs, traditions, and dilemmas for the study of governance (see Bevir and Rhodes 2003, 2006). Any existing 
pattern of rule will have some failings: mind you, different people will have different views about these failings since they are not simply given by experience but rather constructed from interpretations of experience infused with traditions. When people's perceptions of the failings of governance conflict with their existing beliefs, the failures pose dilemmas that push them to reconsider their beliefs and so the traditions that inform those beliefs. Because people confront these dilemmas against the background of diverse traditions, there arises a political contest over what constitutes the nature of the failings and what should be done about them. Exponents of rival positions seek to promote their particular sets of theories and policies. This contest then leads to a reform of governance. Hence any reform can be understood as a contingent product of a contest of meanings in action.

The reformed pattern of rule established by this complex process will display new failings, pose new dilemmas, and be the subject of competing proposals for reform. There will be a further contest over meanings, a contest in which the dilemmas are often significantly different, and the traditions have been modified as a result of accommodating the previous dilemmas.

All such contests take place in the context of laws and norms that prescribe how they should be conducted. Sometimes the relevant laws and norms have changed because of simultaneous contests over their content and relevance. Yet while we can distinguish analytically between a pattern of rule and a contest over its reform, we rarely can do so temporally. Rather, the activity of governing continues during most contests, and most contests occur partly within local practices of governing. What we have, therefore, is a complex and continuous process of interpretation, conflict, and activity that produces everchanging patterns of rule.

A decentred account of governance represents a shift of topos from institutions to meanings in action. It suggests the first wave of narratives on contemporary governance tend to restrain the centrifugal impulse of their account of a differentiated polity. First wave narratives reduce the diversity of governance to a logic of modernization, institutional norms, or a set of classifications or correlations across networks. Their proponents thereby tame an otherwise chaotic picture of multiple actors creating a contingent pattern of rule through their conflicting actions.

A decentred approach implies that governance arises from the bottom-up. Any pattern of governance is a product of diverse practices that are themselves composed of multiple individuals acting on all sorts of conflicting beliefs which they have reached against the background of a range of traditions and in response to varied dilemmas. A decentred approach leads us, then, to replace aggregate concepts that refer to objectified social laws or institutions with one's that we craft to explain the particular beliefs and actions of interest to us. It inspires narratives of traditions and dilemmas.

\section{The British Example}

Contemporary governance in Britain embodies at least four constructions of governance: intermediate institutions, networks of communities, reinventing the constitution, and joined-up government (see Table 1). The actions of elite British policy-makers have been informed by their beliefs in one or other of these narratives. Contemporary British governance is largely the unintended effect of these actions and the competing narratives they embody. Our choice of traditions is conventional and we give a brief example of how each tradition interprets governance. ${ }^{5}$

Inspired by the Tory tradition, Gilmour (1992:198-224) portrayed Thatcher's reforms as a 'series of tactical battles' that wrecked Britain's intermediate institutions, such as the monarchy, the church, the civil service, the judiciary, the $B B C$, and local government. These 'barriers between state and citizen' were torn down, he argues, in the drive to create an enterprise culture and a free market state. Gilmour values the pluralism of intermediate institutions and wants to return to moderation in the 
Table 1: $\underline{\text { Narratives of governance. }}$

\begin{tabular}{|l|l|l|l|l|}
\hline \multirow{2}{*}{} & \multicolumn{2}{|l|}{ TRADITIONS } \\
\cline { 2 - 5 } & Tory & Liberal & Whig & Socialist \\
\hline NARRATIVE OF & Wrecked & Building & Return to the & Joining-up \\
GOVERNANCE & intermediate & networks of & organic & government. \\
& institutions. & communities. & constitution. & \\
\hline STORYLINE & Preserving & Restoring & Evolutionary & Redefining the \\
& traditional & markets and & change. & bureaucratic \\
& authority. & combating state & & state. \\
& & overload. & & \\
\hline
\end{tabular}

exercise of power. The Conservative party encompasses the paternal statism of the High Tories and economic liberalism but during the 1980s and 1990s, the former has become a submerged tradition.

For Liberals, the key to effective governance lay in market competition and bureaucratic reform. In her own words, Margaret Thatcher (1993:48) 'preferred disorderly resistance to decline rather than comfortable accommodation to it'. But the Liberal zeal in refashioning the state was also married to the notion of community. Willetts (1992:71) wanted to claim the notion of an 'overlapping network of communities' as a core principle in the Liberal tradition. So, liberalism reconciles markets and community with the idea of 'micro-conservatism' or 'the particular network of communities which gives each individual life meaning'. The role of the state is to sustain 'a political order in which this multiplicity of communities can survive' (Willetts 1992: 105). Micro-communities populate the boundary between state and civil society, an image with a close affinity to nineteenth century notions of governance as private collectivism.

The Whig tradition lauds the capacity of British political institutions to incorporate and moderate changes. Its response to public sector reform, as in the example provided by Hennessy (1995:734), is 'wherever possible' to use 'traditional and familiar institutions for new purposes' and so to 'go with the grain of Westminster and Whitehall and their traditions'. Empathy with the British constitution leads to calls for a return to the organic constitution. In a similar vein Lord Bancroft (1983:8), a former head of the home civil service argued 'for organic institutional change, planned at a digestible rate' so that reforms work with, 
and so perpetuate, all that is salutary in Britain's constitution and political practice.

New Labour rejects the command bureaucracy model of Old Labour with its emphasis on hierarchy, authority and rules. It rejects municipal socialism and nationalization and 'does not seek to provide centralised 'statist' solutions to every social and economic problem' (Mandelson and Liddle 1996:27; and, for discussion, Bevir 2005). Instead New Labour promotes the idea of networks of institutions and individuals acting in partnerships held together by relations of trust. It favours joined-up government or delivering public services by steering networks of organisations where the currency is not authority (bureaucracy) or price competition (markets) but trust. It exemplifies the shift from the providing state of Old Labour and the minimal state of Thatcherism to the enabling state and the continuing socialist commitment to making that state work. ${ }^{6}$

\section{Resurrection: toward new governance narratives}

A decentred approach suggests governance is a product of diverse practices that are themselves composed of multiple individuals acting on conflicting webs of beliefs rooted in overlapping traditions. Next we want to ask: what does a decentred approach tell us about governance? Our answer will be that it challenges the craving for generality that characterises first wave narratives of governance; it undermines their aspirations to comprehensiveness and in consequence their definitions of contemporary governance.

The craving for generality inspires, first, attempts to explain the highly diverse practices of contemporary governance in terms of a social logic or law-like regularity. In contrast, a decentred approach explains diverse practices of governance by reference to various contingent actions rooted in overlapping and competing traditions. The craving for generality inspires, second, attempts to define contemporary governance by reference to a list of general features or essential properties that are supposed to characterise it in each and every instance. In contrast, a decentred approach provides a series of perspectives on different aspects of governance. It points to a definition of governance as a series of family resemblances, none of which need be always present. The craving for generality inspires, finally, a concept of policy advice based on scientific expertise. In contrast, a decentred approach might encourage a conception of policy advice based on stories that enable listeners to see new aspects of governance.

\section{Explaining Governance}

Comprehensive accounts of contemporary governance typically attempt to explain cases of governance by reference to a social logic. In contrast, a decentred approach prompts us to adopt narrative explanations, which relate actions and practices to the beliefs of the relevant actors, and which situate these beliefs against the background of traditions and dilemmas. We can not explain contemporary governance adequately by reference to allegedly objective social processes. We can explain it only as a contingent pattern of rule that arises out of all kinds of actions. Again, we can not explain these actions by reference to allegedly objective social facts about the actors such as their institutional location. We can explain them as embodying beliefs that the actors adopted against the background of particular traditions and in response to specific dilemmas. In short, we have to adopt a bottom-up approach to the explanation of any pattern of rule.

For example, we have shown how the Tory, Liberal, Whig and Socialist traditions inspired distinctive notions of governance, labelled, respectively, wrecked intermediate institutions, building networks of communities, reinventing the constitution, and joining-up government (see Table 1). It is important to note here that such decentred narratives do not purport to be comprehensive accounts, so 
the Tory, Whig, Liberal, and Socialist traditions do not constitute essential properties that appear in each and every instance of British governance, let alone contemporary governance more generally. To the contrary, a fuller account of even British governance would require us to move beyond Westminster and Whitehall so as to examine the several actors involved in making and implementing public policy within, say, the police, the National Health Service, protest movements and schools, (Bevir and Rhodes 2006). In short, we would decentre governance and policy to explore how actors going about their daily business construct both. Our stories would provide a series of snap-shots of different aspects of governance. Some aspects we might explain in terms of Tory, Whig, Liberal, and Socialist traditions. To explain others we might appeal to other traditions.

So, a decentred approach contrasts sharply with those apparently comprehensive accounts that unpack the essential properties and social logic of contemporary governance. Neither the intrinsic rationality of markets nor the path dependency of institutions decides patterns of governance. Rather, patterns of governance are explained as the contingent constructions of several actors inspired by competing webs of belief formed against the background of diverse traditions. A decentred approach explains shifting patterns of governance by focusing on the actors' own interpretations of their actions and practices. It explores the diverse ways in which situated agents are changing the boundaries of state and civil society by constantly remaking practices as their beliefs change.

\section{Defining Governance}

Because we cannot explain cases of contemporary governance by reference to a comprehensive theory, we cannot define governance in terms of key features. Rather, we can define it only in terms of particular cases. However, the absence of a comprehensive theory of contemporary governance also implies there need be no feature common to all the cases to which we would apply the term. It is futile to search for the essential features of an abstract category that denotes a cluster of human practices. Worse still, the search for allegedly common features can lead political scientists to dismiss the particular cases which alone enable them to understand the abstract category. When we provide a definition or general account of governance, it should be couched as a set of family resemblances.

Once we reject the idea of a comprehensive account of contemporary governance, we can no longer define 'governance' by reference to its allegedly essential properties. Rather, we understand general concepts such as governance by using them in actual cases. Their meaning derives from the ways in which we use them in various contexts. What is more, the absence of a comprehensive account of contemporary governance suggests there are no set ways in which we must - or must not - use the term. There need be no single feature shared by all those cases or narratives to which we would apply the general term 'governance'.

We understand governance as a set of family resemblances. Wittgenstein (1972a) famously suggested that general concepts such as 'game' should be defined by various traits that over-lapped and criss-crossed in much the same way as do the resemblances between members of a family their builds, eye colour, gait, personalities. He considered various examples of games to challenge the idea that they all possessed a given property or set of properties - skill, enjoyment, victory and defeat - by which we could define the concept. Instead, he suggested that the examples exhibited a network of similarities, at various levels of detail, so that they coalesced even though no one feature was common to them all.

We do not master such family resemblances by discovering a theory or rule that tells us precisely when we should and should not apply it. Our grasp of the concept consists in our ability to provide reasons why it should be applied in one case but not another, our ability to draw analogies with other cases, and our ability to point to the criss-crossing similarities. 
Our knowledge of 'governance' is analogous to our knowledge of 'game' as described by Wittgenstein: it is 'completely expressed' by our describing various cases of governance, showing how other cases can be considered as analogous to these, and suggesting that we would be unlikely to describe yet other cases as ones of governance.

No doubt some of the family resemblances that characterise governance derive from a focus on meaning in action and so apply to all patterns of rule. A decentred approach highlights, first, a more diverse view of state authority and its exercise. All patterns of rule arise as the contingent products of diverse actions and political struggles informed by the varied beliefs of situated agents. First wave narratives of contemporary governance suggest the New Right's reinvention of the minimal state and the more recent rediscovery of networks are attempts to find a substitute for the voluntaristic bonds weakened by state intervention. A decentred approach suggests, in addition, that the notion of a monolithic state in control of itself and civil society was always a myth. The myth obscured the reality of diverse state practices that escaped the control of the centre because they arose from the contingent beliefs and actions of diverse actors at the boundary of state and civil society. The state is never monolithic and it always negotiates with others. Policy always arises from interactions within networks of organisations and individuals. Patterns of rule always traverse the public, private, and voluntary sectors. The boundaries between state and civil society are always blurred. Transnational and international links and flows always disrupt national borders. In short, state authority is constantly being remade, negotiated, and contested in widely different ways within widely varying everyday practices.

Second, these everyday practices arise from situated agents whose beliefs and actions are informed by traditions and expressed in stories. In every government department, we can identify departmental traditions, often embodied in rituals and routines. They might range from specific notions of accountability to the ritual of the tea lady. Actors pass on these traditions in large part by telling one another stories about how things are done, and about what does and does not work. For example, British civil servants are socialized into the broad notions of the Westminster model, such as ministerial responsibility, as well as the specific ways of doing things around here; they are 'socialized into the idea of a profession', and learn 'the framework of the acceptable' (Bevir and Rhodes 2006: chapter 7). Governance is not any given set of characteristics. It is the stories people use to construct, convey, and explain traditions, dilemmas and practices.

A decentred approach also might help to highlight a third family resemblance that characterises British governance but might not be found in patterns of rule in other times or places. In Britain, the reforms of the New Right and New Labour do indeed appear to have brought something of a shift from hierarchy to markets to networks. While this shift is widely recognised, a decentred approach suggests, crucially, that it takes many diverse forms. For the police, the shift from hierarchy to markets to networks poses quite specific dilemmas: they know how to rewrite the rulebook, manage a contract or work with neighbourhood watch but they struggle to reconcile ways of working, believing they conflict and undermine one another (Bevir and Rhodes 2006: chapter 9). For doctors, the equivalent shift poses quite different dilemmas: the key issue is how to preserve the medical model of health and medical autonomy from managerial reforms that stress hierarchy and financial control (Bevir and Rhodes 2006: chapter 8).

A fourth family resemblance is that the central state has adopted a less hands-on role. Its actors are less commonly found within various local and sectoral bodies, and more commonly found in quangos concerned to steer, co-ordinate and regulate such bodies. Once again, a decentred approach suggests, crucially, that such steering, co-ordination and regulation take many diverse forms. In Britain, the preeminent example is 'joined-up' government 
as the Blair Government seeks to devise policy instruments that integrate both horizontally across central government departments and vertically between central and local government and the voluntary sector (Bevir 2005:83-105).

A decentred approach highlights the resemblances that contribute to a general characterisation of governance and a more specific characterisation of governance at least in Britain. Nonetheless, it disavows any logic to the specific forms governance takes in particular circumstances. Hence a decentred approach resolves the theoretical difficulties that beset first wave narratives of contemporary governance. It avoids the unacceptable suggestion that institutions fix the actions of individuals in them rather than being products of those actions. It replaces unhelpful phrases such as path-dependency with an analysis of change rooted in the beliefs and practices of situated agents. And yet it allows political scientists to offer aggregate studies by using the concept of tradition to explain how they come to hold those beliefs and perform those practices.

\section{Policy advice}

The craving for generality appears not only in the desire for comprehensive accounts of contemporary governance but also in the concept of policy advice as scientific expertise. We want to highlight, in contrast, three implications of a decentred approach for practitioners. First, the contingent nature of human practices challenges the idea of expertise as a basis for policy. It implies, in other words, that comprehensive accounts can not guide policy-makers in the way they often purport to. Second, narratives and cases offer a different type of policy advice from the kind of expertise proffered by those who purport to provide comprehensive accounts. Instead of revealing policy consequences through insights into a social logic or law-like regularities, they enable policy-makers to see things differently; they exhibit new connections within governance and new aspects of governance. Third, the process of seeing differently is a dialogical one. Typically we see new aspects of a policy area or problem when someone tells us a story that highlights them. Hence policy-makers would be well advised to engage in more dialogic modes of policy formation that involve them in conversations with diverse groups of citizens. In short, our governance stories point to policy advice as stories that enable listeners to see governance afresh.

Most policy-oriented work on contemporary governance seeks to improve the ability of the state to manage the mix of hierarchies, markets and networks that have flourished since the 1980s. A recent example is the call for evidence-based policy making in the UK (see for example, Cabinet Office 2001; Davies et al. 2000). This work treats government departments, local authorities, markets, and networks as fixed structures that governments can manipulate using the right tools (and for a massive survey of such tools see Salamon 2002). A decentred approach encourages us, in contrast, to foreswear management techniques and strategies but, and the point is crucial, to replace such tools with learning by telling stories and listening to them.

There is now a growing literature on just such an 'the interpretive turn' in policy analysis, public administration and organization theory. ${ }^{7}$ The behavioural revolution in the social sciences marginalized storytelling but it is being rediscovered in several disciplines - law, psychology, even economics. In policy analysis, as Dryzek (1993:222) points out, there are many social science frames of reference. Each frame 'treats some topics as more salient than others, defines social problems in a unique fashion, commits itself to particular value judgements, and generally interprets the world in its own particular and partial way'. And this multiplicity of 'incommensurable analytical frames' dealt a 'devastating' blow to the 'authoritative ambitions' of policy analysis. Instead of such ambitions, we have policy analysis through dialogue. Thus Schram (1993:252) argues for 'those approaches to examining policy that emphasize how the initiation, contestation, adoption, implementation, and evaluation 
of any policy are shaped by the discursive, narrative, symbolic practices which socially construct our understanding of problems, methods of treatment and criteria of success'.

In similar vein, van Eeten et al. (1996) record the rediscovery of storytelling in the subfield of public administration. They distinguish between storytelling by administrators and storytelling by scholars to make the important point that this latest intellectual fashion has its feet firmly on the ground. In both public and private organizations managers use stories not only to gain and pass on information and to inspire involvement but also as the repository of the organization's institutional memory.

Morgan's (1993) approach to 'storytelling' stresses creating new metaphors, new stories, with which to understand an organisation. It aims to: improve our abilities to see and understand situations in new ways; find new images for new ways of organising; and create shared understandings that empower people and develop their capacities for selforganization (Morgan 1993:2-19 and Appendix A). It is 'the art of framing and reframing'. It uses 'images, metaphors, readings and storylines to cast situations in new perspective and open possibilities for creative action'. Metaphors are central to this process. They use paradox to 'break the bounds of normal discourse'. They require the 'users to find and create meaning'. But they work only if they 'ring true, hit a chord and resonate' (Morgan 1993: 290). In sum, 'organization always hinges on the creation of shared meaning and shared understandings' (Morgan 1993: 11; see also Weick 1995: chapter 8). In short, we seek to make the simple point that a decentred approach encourages storytelling as a way of providing guides for managers.

Given that much of our argument about policy advice is general, it is important to bring it down to earth with a thud. Most if not all policy advisers will accept that the art of storytelling is an integral part of their work. Such phrases as: 'Have we got our story straight?', 'Are we telling a consistent story?', and 'What is our story?' abound. The basis for much advice is the collective memory of the department, its traditions if you will. It is an organized, selective re-telling of the past to make sense of the present. Advisors explain past practice and events to justify recommendations for the future. In short, our stress on storytelling is not an example of academic whimsy. Our approach overlaps with the everyday practice of advisors.

\section{Conclusion}

In sum, the life of contemporary governance was the somewhat positivist story of the shift from hierarchy to markets to networks. A decentred approach brings about the death of this first wave narrative, arguing there is no single account or theory of contemporary governance, only the differing constructions of several traditions. There is no necessary logical or structural process determining the form contemporary governance takes, neither a process based on the intrinsic rationality of markets nor one on the path dependency of institutions. The resurrection of governance lies in accepting that it arises out of diverse actions and practices inspired by varied beliefs and traditions. Patterns of rule arise as the contingent products of diverse actions and political struggles informed by the beliefs of agents as they arise in the context of traditions.

These conclusions apply, moreover, whether we are talking about the civil service, public sector reform, governing structures, or state-civil society relations. There may be some agreement that the boundary between state and civil society is being redrawn, and that the form and extent of state intervention is changing, but there is little agreement on how, why or whether it is desirable. If we adopt a broad concept of governance as the relation of the state to civil society, governance as private collectivism can appear to have been eroded by successive periods of centralization fuelled by the two world wars. The reinvention of the minimal state by the New Right and the later discovery 
of networks are attempts to find a substitute for the voluntary bonds diminished by state intervention and the erosion of intermediate institutions such as local government. We are witnessing, in this view, the search for an extended role for civil society in an era of large organizations.

Appeals to networks can be seen not only as a counterweight to the centralization of the 1960s and 1970s, but also as an example of how governing in late modern society involves engaging individuals in governance in their everyday life (as employees, users, citizens). It has come to do so because of the contingent ways in which politicians

\section{References}

Bancroft, Lord 1983. 'Whitehall: Some Personal Reflections'. Suntory-Toyota lecture, London School of Economics and Political Science, 1 December.

Barker, R. 1994. Politics, Peoples and Governments. Themes in British Political Thought since the Nineteenth Century Macmillan:.London.

Bevir, M. 2002. 'Sidney Webb: Utilitarianism, Positivism, and Social Democracy', Journal of Modern History. 74(2):217-252.

Bevir, M. 2005. New Labour: A Critique. Routledge:London.

Bevir, M. and Rhodes, R. A. W. 2003. Interpreting British Governance. Routledge: London.

Bevir, M. and Rhodes, R. A. W. 2006. Governance Stories. Routledge: London.

Cabinet Office 2001. Better Policy Making. (UK)Cabinet Office:London.

Davies, H., S.M. Nutley and P.C. Smith eds. 2000. What works? Evidence-based policy and practice in public services. Policy Press: Bristol.

Dryzek, J. S. 1993. 'Policy Analysis and Planning: from science to argument', in F. Fischer and J. Forester (eds.), The Argumentative Turn in Policy Analysis and Planning.Duke University Press: Durham.

Fischer, F. 2003. Reframing Public Policy. Oxford University Press: Oxford.

Fox, A. 1974. Beyond Contract: Work, Power and Trust Relations. Faber: London.

Frances, J. et al. 1991. 'Introduction'. In G. Thompson et al (eds), Markets Hierarchies and Networks: the coordination of social life. Sage: London.

Gilmour, I. 1992. Dancing with Dogma: Britain under Thatcherism. Simon \& Schuster: London. from within the various traditions responded to the dilemma of overload by introducing reforms that ask individuals to get involved. So, politicians in the liberal tradition sought to involve individuals in markets while New Labour seeks their involvement in networks. And, again, such citizen involvement is not the result of any necessary structural process but a contingent outcome of political actions and beliefs. We use the notion of governance to develop a more diverse view of state authority in its relationship to civil society. And we seek to explain patterns of governance in terms of contingent traditions and dilemmas cast at various levels of aggregation.

Hajer, M. A. and H. Wagenaar eds. 2003. Deliberative Policy Analysis. Understanding governance in a networked society. Cambridge University Press: Cambridge.

Hennessy, P. 1989. Whitehall. Secker \& Warburg: London.

Mandelson, P. and R. Liddle 1996. The Blair Revolution: Can New Labour Deliver? Faber \& Faber: London.

Marinetto, M. 2003. 'Governing beyond the centre: a critique of the Anglo-Governance School', Political Studies, 51:592-608.

Morgan G. 1993. Imaginization. Sage: London.

Pearson, R. and G. Williams 1984. Political Thought and Public Policy in the Nineteenth Century. Longman: London.

Powell, W. 1991. 'Neither Market Nor Hierarchy: network forms of organization'. In Thomson, G. et al., (eds), Markets Hierarchies and Networks: the coordination of social life. Sage: London.

Powell, W. 1996. 'Trust-based Forms of Governance'. In R. M. Kramer and T. Tyler (eds). Trust in Organizations: frontiers of theory and research. Sage: London.

Rein, M. 1976. Social Science and Public Policy. Penguin Books: Harmondsworth.

Rhodes, R. A. W. 1988. Beyond Westminster and Whitehall. Unwion-Hyman: London.

Rhodes, R. A. W. 1997a. Understanding Governance. Open University Press: Buckingham and Philadelphia.

Rhodes, R. A. W. 1997b. 'It's the Mix that Matters: From Marketisation to Diplomacy', Australian Journal of Public Administration, 56:40-53. 
Rhodes, R. A. W. ed.2000. Transforming British Governance. 2 vols. Macmillan: London.

Richards, D and M.J. Smith 2002. Governance and Public Policy in the UK. Oxford University Press: Oxford.

Salamon, L. M. ed. 2002. The Tools of Government: A Guide to the New Governance. Oxford University Press: Oxford.

Schram, S. F. 1993. 'Postmodern Policy Analysis: Discourse and Identity in Welfare Policy', Policy Sciences, 26:249-70.

Smith, M. J. 1999. The Core Executive in Britain. Macmillan: London.

Stoker, G. ed. 2000. The New Politics of British Local Governance. Macmillan: London.

Stoker, G. 2004. Transforming Local Governance.Palgrave: Houndmills, Basingstoke.

Thatcher, M. 1993. The Downing Street Years. HarperCollins: London.

Thompson, G. 1993. 'Network co-ordination', in R. Maidment and G. and Thompson eds. Managing the United Kingdom. Sage: London.

Tyler, T. and P. Degoey 1996. 'Trust in Organisational Authorities', in R. M. Kramer and T. Tyler eds. Trust in Organizations: Frontiers of Theory and Research. Sage: London.

van Eeten, M. J. G., M.J.W van Twist and P.R Kalders 1996. 'Verhallen vertellen: van een narratieve bestuurskunde naar een postmoderne beweerkunde?' Bestuurskunde 5(4): 168-189. English translation supplied by Mark van Twist.

Weick, K. E. 1995. Sensemaking in Organizations. Sage: London.

Willetts, D. 1992. Modern Conservatism. Penguin Books: Harmondsworth.

Wittgenstein, L. 1972a. Philosophical Investigations. Translated by G. Anscombe. Basil Blackwell: Oxford.

Wittgenstein, L. 1972b. The Blue and Brown Books. Blackwell: Oxford.

Wright, V. and J. Hayward 2000. 'Governing from the Centre: Policy Co-ordination in Six European Core Executives'. In R. A. W. Rhodes ed. Transforming British Government. Volume 2. Changing Roles and Relationships. Macmillan: London.

Yanow, D. 1999. Conducting Interpretive Policy Analysis. Sage: Newbury Park, CA.

\section{Endnotes}

1 We use the phrase 'contemporary governance' to refer to the contingent empirical features of modernist-empiricist accounts of governance. We use the term governance to refer to the family resemblances that derive from our approach.

${ }^{2}$ We derive the argument that some concepts, including governance, are best elucidated through studies of particular cases that reveal family resemblances rather than essential properties from Wittgenstein's famous discussion of 'game' (Wittgenstein 1972a). In his preliminary sketch of just this discussion, he explicitly contrasts this position with a 'craving for generality' he ascribes to inappropriate attempts to model all knowledge on natural science (Wittgenstein 1972b: 17-20).

${ }^{3}$ It would use too much space to provide supporting quotations but the point is well made in, for example, Marinetto's 2003 discussion of the 'Anglo-Governance School'. For specific examples see: Rhodes 1988, 1997a and 2000, Richards and Smith 2002, Smith 1999, and Stoker 2000 and 2004.

${ }^{4}$ On trust see Fox 1974, Kramer and Tyler 1996, Powell 1996, Rhodes 1997b Thompson 1993 , and Tyler and Degoey 1996.

${ }^{5}$ Our choice of traditions for Britain is conventional (see for example: Barker 1994, Pearson and Williams 1984). Of course, in any society there is a multiplicity of traditions. We adopt a pragmatic notion of tradition. Investigators choose a particular tradition to explain whatever set of beliefs or actions happen to be of interest to them. Traditions are essentially artefacts and the justification for any choice of traditions lies in the claim that they best explain what is of interest, in our case changes in governance, not in the claim that such traditions are given or natural.

${ }^{6}$ Of course, there are several inherited strands in New Labour thinking. For example, it is heir to the 'managerialism' that was a distinct part of the Fabian tradition (see for example Bevir 2002). For a detailed unpacking of not only the influence of the socialist tradition on New Labour but also of the socialist response to the dilemmas posed by the New Right, see Bevir 2005.

${ }^{7}$ We can only illustrate the point in this article. On the interpretive turn in policy analysis generally and storytelling in particular see: Fischer 2003, Hajer and Wagenaar 2003, Morgan 1993, Rein 1976, van Eeten et al. 1996, Weick 1995, and Yanow 1999. 